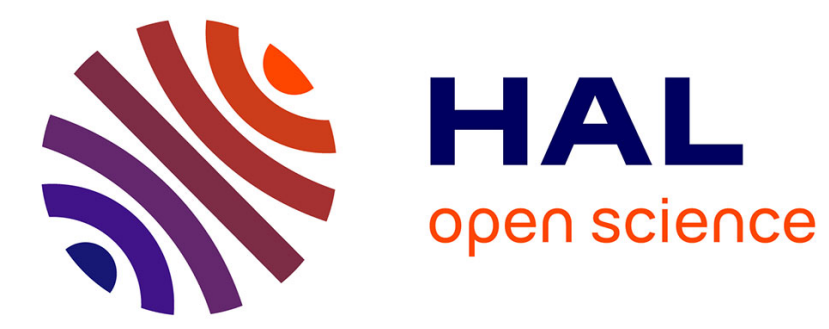

\title{
Modelling a siphon on quota transfers: application to milk in France
}

Herve Guyomard, Louis Pascal Mahe

\section{To cite this version:}

Herve Guyomard, Louis Pascal Mahe. Modelling a siphon on quota transfers : application to milk in France. 1994, 13 p. hal-01601611

\section{HAL Id: hal-01601611 \\ https://hal.science/hal-01601611}

Submitted on 2 Oct 2017

HAL is a multi-disciplinary open access archive for the deposit and dissemination of scientific research documents, whether they are published or not. The documents may come from teaching and research institutions in France or abroad, or from public or private research centers.
L'archive ouverte pluridisciplinaire HAL, est destinée au dépôt et à la diffusion de documents scientifiques de niveau recherche, publiés ou non, émanant des établissements d'enseignement et de recherche français ou étrangers, des laboratoires publics ou privés.

\section{(ㅇ)(1) $\$$}

Distributed under a Creative Commons Attribution - NonCommercial - NoDerivatives $\mid 4.0$ 


\section{MODELLING A SIPHON ON QUOTA TRANSFERS: APPLICATION TO MILK IN FRANCE}

Hervé GUYOMARD, Louis P. MAHE 


\section{Modelling a siphon on quota transfers: application to milk in France}

Abstract: We develop an analytical framework which permits to analyse the consequences of imposing a siphon on quota transfers for general quota supply and demand functions. A siphon is a tax in kind levied on quota exchanges so as to generate quantities which could be transferred to deserving some specific producers and new entrants. The analytical framework is based on a microeconomic model of producer behaviour in a tradable quota regime from which we derive supply and demand functions for quota rights at the industry level. We then analyse the three options for the siphon defined by Burrell (1989) in terms of price, quantity and welfare effects. We finally applied this theoretical framework to the case of milk quotas in France using a sample of dairy farmers for the year 1991. The analysis developed in this note extends that of Burrell, and Swinbank and Peters (1990).

Keywords: quota market, siphon, duality theory, milk.

\section{Introduction}

Supply management designate those regulatory activities that control the level of production and fix the price paid to producers. If the rationing is applied equiproportionnally to individual producers with different cost-output structures, marginal costs at produced quantities will differ across firms and a dead weight loss appears which corresponds to an upward shift of the industry supply curve (see, e.g., Alston, 1981 ; Burrell, 1989). In comparison with the situation of unlimited support at the same guaranteed price, the total producer welfare loss results thus from both the reduction in the industry supply due to the global quota and the inefficient distribution of individual quotas among producers. A market for quota rights can, by equating marginal costs between producers, eliminate this upward shift and restablish cost-efficiency at the industry level. On the basis of this reasoning, one can conclude that transferable quotas are more efficient than non transferable quotas (see, e.g., Alston, 1981, 1992 ; Harvey, 1984; Dawson, 1991).

The main beneficiaries of a quota policy are producers in place when quotas were allocated gratis. The costs are borne mainly by consumers and by new entrants who have to pay for quotas. As noted by Burrell (p. 112), when quota is reallocated by the market, the selection is made according to the candidate's access to capital. One option for lowering this entry barrier is to introduce a siphon on quota transfers. A siphon is a tax in kind levied on exchanged quantities for redistributing to new entrants and/or priority producers. Burrell analyses, graphically, three options for a siphon on quota transfers. The first option corresponds to the case where the cost of the siphon is totally funded from outside the market. In the second option, a part of the financial burden is borne by quota purchasers. The third option is self-funding and the burden is shared between quota sellers and buyers. Swinbank and Peters (1990) consider in detail this third option and show that the effect on suppliers depends upon the demand elasticity (if demand is elastic, suppliers of quotas can gain and the greater is their gain the more elastic is demand (Swinbank and Peters, p. 126)). 
The analysis developed in this paper extends that of Burrell, and Swinbank and Peters. We propose an analytical framework which permits to explore the consequences of imposing a siphon on quota transfers for general quota supply and demand functions (we do not make particular assumptions about the form of these functions). The analytical framework is based on a microeconomic model of producer behaviour in a tradable quota regime from which we derive supply and demand functions for quota rights at the industry level. We characterise the comparative statics of the equilibrium rental price and exchanged quantity. We show, in particular, that the equilibrium rental price absorbs any change in the output price and that exchanged quantity does not depend on output price. These results extend those of Hubbard (1992) who defines, but without formalising, the comparative statics of the equilibrium rental price, and of Burton (1989) who notes, on the basis of empirical simulations, that an increase in the price of the output under quota has «no effect on any of the results apart from increasing the market clearing price of quota by the output price increase». Within this general framework, we then analyse the three options for the siphon defined by Burrell in terms of price, quantity and welfare effects. We finally applied this theoretical framework to the case of milk quotas in France using a sample of dairy farmers for the year 1991.

The theoretical framework is presented in Section 2. Section 3 is devoted to the empirical application. Section 4 concludes.

\section{Theoretical framework}

i) the no-siphon quota market

Consider a profit maximising farmer $n, \quad n=1, \ldots, N$, who produces the output $y^{n}$ according to the well-behaved cost structure $C^{n}\left(y^{n}, w, \bar{Z}^{n}\right)$ where $w$ is the market price vector of variable input quantities $x^{n}$ (raw materials) and $\bar{Z}^{n}$ is the quasi-fixed factor quantity vector (capital, land and labour). The farmer is a price-taker in the output and variable input markets. Output $y^{n}$ is constrained by an individual quota at level $\bar{y}^{n}$ and quotas can be freely traded among producers for one production cycle. Let $r$ be the rental price of quota. The farmer's behaviour in this regime of tradable quota rights is summarised by the following programme ${ }^{1}$ :

(1) $\max _{y^{n}, q^{n}}\left[\pi=p y^{n}-C^{n}\left(y^{n}, w, \bar{Z}^{n}\right)+r q^{n} ; y^{n}=\bar{y}^{n}+q^{n}\right] \equiv \pi^{n}\left(p-r, w, \bar{Z}^{n}\right)+r \bar{y}^{n}$

where $r q^{n} \geq 0$ represents the cost of leasing additional quota $q^{n}$ at a price $r$ and $r q^{n} \leq 0$ represents the earnings from leasing out part or all of initial quota, also at a price $r$ per unit. $\pi^{n}\left(p-r, w, \bar{Z}^{n}\right)$ is the short-run unrationed profit function corresponding to the no-quota regime and defined by:

(2) $\max _{y^{n}}\left[\pi=(p-r) y^{n}-C^{n}\left(y^{n}, w, \bar{Z}^{n}\right)\right] \equiv \pi^{n}\left(p-r, w, \bar{Z}^{n}\right)$ 
As it is well known, there is room for mutually beneficial exchange of quota between producers as long as there remain differences in marginal costs: producer $n$ will lease additional quota if his marginal cost is lower than the difference $p-r$ and he will lease out part or all of his initial quota endowment if his marginal cost is greater than $p-r$. Quota will be exchanged until the marginal costs of production of all firms are equalised (see, e.g., Butcher and Heady, 1963; Moschini, 1984; Cox, 1987; Hubbard, 1992; Babcock and Foster, 1992, Hollander, 1993), i.e.,

(3) $\partial C^{n}\left(y^{t, n}, w, \bar{Z}^{n}\right) / \partial y=p-r \quad \forall n \in N$

where $y^{t, n}$ represents the optimal level of output in the regime of tradable rights.

Equation (3) implicitly defines the output supply function $y^{t, n}\left(p-r, w, \bar{Z}^{n}\right)$ which can also directly be derived from the short-run unrationed profit function, evaluated at price $p-r$, by Hotelling's lemma:

(4) $y^{t, n}\left(p-r, w, \bar{Z}^{n}\right)=\partial \pi^{n}\left(p-r, w, \bar{Z}^{n}\right) / \not p \quad \forall n \in N$

Competitive market equilibrium for quota rights is defined by a quota rental price $r^{*}$ such that the quota market clears, i.e., a rental price $r^{*}$ where the industry excess demand for quota rights is brought to zero:

(5) $\sum_{n=1}^{N} q^{t, n}\left(p-r^{*}, w, \bar{Z}^{n}, \bar{y}^{n}\right)=\sum_{n=1}^{N} y^{t, n}\left(p-r^{*}, w, \bar{Z}^{n}\right)-\sum_{n=1}^{N} \bar{y}^{n}=0$

Equation (5), solved for $r$, defines the equilibrium rental price $r^{*}$ of the quota as a function of exogenous variables, i.e., $\bar{y}^{n}, p, w, \bar{Z}^{n}$ and $N$. The comparative statics of this equilibrium rental price $r^{*}$ is obtained by total differentiating of (5) and solving for $d r^{*}$ :

(6) $d r^{\cdot}=d p-\left(\sum_{N} \pi_{p p}^{n}\right)^{-1}\left(\sum_{N} d \bar{y}^{n}-\sum_{N} \pi_{p w}^{n} d w-\sum_{N} \pi_{p Z}^{n} d \bar{Z}^{n}\right)$

Equation (6) shows that the equilibrium rental price, i) absorbs any change in the output price $\left(\partial^{*} / \partial p=1\right)$, ii) is decreasing in the aggregate quota level, iii) is decreasing in the prices of non inferior variable inputs, and iv) is increasing in the quantities of non inferior quasi-fixed factors ${ }^{2}$. Furthermore, it is worth noting that the equilibrium rental price does not depend on individual quota endowments $\bar{y}^{n}$, but on the aggregate quota level $\bar{Y}$.

Figure 1 illustrates the determination of equilibrium lease rate and traded quantity. The supply of milk quota is noted $S$ and the demand for milk quota is noted $D$. The intersection of these two curves determines the equilibrium price $r^{*}$ and traded quantity $Q^{*}$. With respect to the non tradable 
quota regime, quota sellers' welfare increases by area $A$ and quota purchasers' welfare increases by area $B$.

\section{(insert Figure 1)}

\section{ii) introduction of a siphon on quota transfers}

A siphon is a tax in kind levied on quota exchanges so as to generate quantities which could be transferred to deserving some specific producers and new entrants to dairying. Following Swinbank and Peters, we make the simplifying assumption that recipients of siphoned quota were not previously potential purchasers of quota and do not become potential suppliers of quota. We then consider the three alternative methods of operating a siphon defined by Burrell, methods which differ in function of the sharing of the financing burden between quota purchasers, quota sellers and/or taxpayers. We note $r^{s}$ the quota supply price, $S\left(r^{s}\right)$ the aggregate quota supply function, $r^{d}$ the quota demand price and $D\left(r^{d}\right)$ the aggregate quota demand function. We suppose that a proportion $1-\mu$ of transferred quantities is confiscated for redistributing. The new supply curve $S^{\prime}\left(r^{s}\right)$ which determines the quantity available for purchase on the market is then derived from $S\left(r^{s}\right)$ by a pivotal shift, i.e., $S^{\prime}\left(r^{s}\right)=\mu S\left(r^{s}\right)$. Prices and quantities in the three options for the siphon are indiced by $i=1,2,3$.

Under option one, the cost of the siphon is totally borne by taxpayers. The quota market determines a common price for sellers and buyers which satisfies the following equilibrium condition:

(7) $\log D\left(r_{1}^{*}\right)=\log S^{\prime}\left(r_{1}^{*}\right)=\log \mu+\log S\left(r_{1}^{*}\right)$

By differentiation of (7) with respect to $\mu$ and solving for $\partial \log r_{1}^{*} / \partial \log \mu$, one obtains:

(8) $\partial \log r_{1}^{*} / \partial \log \mu=1 /\left(\partial \log D / \partial \log r^{d}-\partial \log S / \partial \log r^{s}\right)<0$

The market equilibrium is thus established at a price $r_{1}^{*}$ higher than without the siphon which implies that quota sellers' welfare increases and that quota purchasers' welfare decreases. This situation is depicted graphically on Figure 2. Quantities supplied increase from $Q^{*}$ to $Q_{1}^{* S}$, but quantities bought on the market decrease from $Q^{*}$ to $Q_{1}^{* d}$. Quota sellers' welfare increases by area bdeg and quota purchasers' welfare decreases by area bceg. The cost of the siphoned quantity is equal to $\left(Q_{1}^{* s}-Q_{1}^{* d}\right) r_{1}^{*}$. It corresponds to area $c d j l$ and must be funded from outside the market.

\section{(insert Figure 2)}

Under option two, the cost of the siphon is supported by taxpayers and quota purchasers. The price received by quota sellers is the no-siphon price $r^{*}$. The quantity supplied is thus 
$Q_{2}^{* s}=Q^{*}=S\left(r^{*}\right)$ and the quantity available for purchase is $Q_{2}^{* d}=\mu Q_{2}^{* s}$. A wedge is driven between the seller and buyer price, and the latter is solution of the following equation:

(9) $\log D\left(r_{2}^{* d}\right)=\log \mu+\log S\left(r^{*}\right)$

By differentiation of (9) with respect to $\mu$ and solving for $\partial \log r_{2}^{* d} / \partial \log \mu$, one obtains:

(10) $\partial \log r_{2}^{* d} / \partial \log \mu=1 /\left(\partial \log D / \partial \log r^{d}\right)<0$

Equation (10) shows that the demand price $r_{2}^{* d}$ under option two is higher than the no-siphon price $r^{*}$. A comparison of (8) and (10) shows that the demand price $r_{2}^{* d}$ under option two is higher that the demand price $r_{1}^{*}$ under option one, i.e., that quota purchasers suffer an additional welfare loss under option two with respect to option one. Under this second scheme, quota sellers' welfare is unchanged (with respect to the no-siphon situation). The cost of the siphon is equal to $\left(Q_{2}^{* s}-Q_{2}^{* d}\right) r^{*}$ and is partly funded by quota purchasers for the amount $\left(r_{2}^{* d}-r^{*}\right) Q_{2}^{* d}$ and partly from outside the market for the difference. The scheme is self-financing if $\left(r_{2}^{* d}-r^{*}\right) Q_{2}^{* d}=\left(Q_{2}^{* s}-Q_{2}^{* d}\right) r^{*}$, i.e., if $\mu r_{2}^{* d}=r^{*}$. This condition holds if $\partial \log r_{2}^{* d} / \partial \log \mu=-1$, i.e., if the elasticity of demand for quota equal -1 (see equation (10)).

Under option three, the cost of the siphoned quantity is funded by quota purchasers and sellers only. Equilibrium prices and quantities are then determined by the following system:

(11a) $\log D\left(r_{3}^{* d}\right)=\log \mu+\log S\left(r_{3}^{* s}\right)$

(11b) $\log r_{3}^{* s}=\log \mu+\log r_{3}^{* d}$

By differentiation of equations (11a) and (11b) with respect to $\mu$, one yields:

(12a) $\partial \log D / \partial \log r^{d} \partial \log r_{3}^{* d} / \partial \log \mu=1+\partial \log S / \partial \log r^{s} \partial \log r_{3}^{* s} / \log \mu$

(12b) $\partial \log r_{3}^{* s} / \partial \log \mu=1+\partial \log r_{3}^{* d} / \partial \log \mu$

Substituting (12b) into (12a), and solving for $\partial \log r_{3}^{* d} / \partial \log \mu$ and $\partial \log r_{3}^{* s} / \partial \log \mu$, one obtains:

(13) $\partial \log r_{3}^{* s} / \partial \log \mu=\left(1+\partial \log D / \partial \log r^{d}\right) /\left(\partial \log D / \partial \log r^{d}-\partial \log S / \partial \log r^{s}\right)$

(14) $\partial \log r_{3}^{* d} / \partial \log \mu=\left(1+\partial \log S / \partial \log r^{s}\right) /\left(\partial \log D / \partial \log r^{d}-\partial \log S / \partial \log r^{s}\right)$ 
Equation (13) shows that the impact of the third option on the equilibrium supply price $r_{3}{ }^{*}$ is indeterminate. If quota demand is inelastic (respectively elastic), this price will be higher (lower) than the no-siphon price. The limiting case corresponds to an elasticity of demand for quota equal to -1 which leads to a supply price unchanged, i.e., $r_{3}^{* s}=r^{*}$. Therefore, sellers' welfare increases, remains unchanged or decreases depending on a demand elasticity greater, equal or smaller than -1 .

Equation (14) shows that the equilibrium demand price $r_{3}^{* d}$ is always higher than the nosiphon price $r^{*}$, i.e., that purchasers' welfare decreases. By comparing (14) and (8), one easily verifies than $r_{3}^{* d} \geq r_{1}^{* d}$, i.e., that quota purchasers suffer an additional welfare loss under option three with respect to option one. By comparing (14) and (10), one verifies also that $r_{3}^{* d}>r_{2}^{* d}$ when demand is elastic and that $r_{3}^{* d}<r_{2}^{* d}$ when demand is inelastic. In the case of a demand elasticity of -1 , $r_{3}^{* d}=r_{2}^{* d}$ and equilibria under options two and three coincide.

These second and third options are illustrated by Figure 3 and Figure 4, respectively. Under option two, quantities supplied are unchanged at $Q^{*}$ but quantities bought on the market decrease from $Q^{*}$ to $Q_{2}^{* d}$, thereby raising the demand price to $r_{2}^{* d}$. Under option three, total supply is restricted to $Q_{3}^{* s}<Q^{*}$ if demand is inelastic, thereby decreasing the supply price from $r^{*}$ to $r_{3}^{* s}$. Market purchases fall to $Q_{3}^{* d}$, and demand price increases from $r^{*}$ to $r_{3}^{* d}$.

\section{(insert Figure 3 and Figure 4)}

\section{Empirical application to French milk producers}

The previous theoretical framework is applied to a sample of dairy or predominantly dairy farms in France for the year 1991. The data are taken from the European Community's Farm Accountancy Data Network (FADN). In total there are 1599 farms in the sample and these farms obtain more than $75 \%$ of their total return from the dairy enterprise. A restricted cost function is specified and estimated from which we derive marginal cost functions. We characterise the no-siphon quota market at the equilibrium, i.e., rental price of quota, optimal milk supplies, exchanged quantities and producer welfare changes. We then estimate the quota supply and demand functions at the industry level from which we analyse the consequences of the three options for a siphon on marketed quotas.

i) the cost function

Burrell performed a probit analysis to identify the factors which influence the probability that a producer will purchase or lease quota. Her model is applied on data for England and Wales where a quota market exists. Her analysis shows that "purchase models fit better when long-run marginal cost is used and leasing models fit at least as well with short-run as with long-run marginal cost. Therefore, 
estimated long-run marginal cost is used in the purchase functions, short-run marginal cost in the leasing functions" (p. 106). We follow this approach by assuming that the leasing market may be defined from the short-run or restricted marginal cost of milk production.

Only the variable input costs are known for each sampled farm and it is therefore not possible to obtain information for the prices of variable inputs. Because of this, we assume that all farmers face the same prices for all raw materials (animal feed, fertilisers, pesticides, ...). This assumption allows us to specify a restricted cost function which depends on output quantities (milk $y_{1}$ and other products $y_{2}$ ) and quasi-fixed factor quantities (capital $Z_{1}$, land $Z_{2}$ and labour $Z_{3}$ ). Age of the farmer (denoted by $A$ ) is included as an additional explanatory variable in order to take into account individual effects (i.e., human capital and experience). In the same way, regional dummy variables $D_{k}(k=1, \ldots, 18)$ are also included.

The empirical work is based on a truncated quadratic restricted cost function. This is a special case of the more general quadratic specification, allowing only linear interactions between milk output and other variables (other products, capital, land, labour and age), other products and other products, and capital and capital. We experimented with the full quadratic specification and found that it was overparametrised. Furthermore, it is worth noting that the simplified specification is not rejected at the $5 \%$ level of significance when tested against the full specification. The choice of the quadratic form is essentially pragmatic and motivated by the simplicity of calculations since marginal cost functions are linear in $y_{1}$ in this case.

The estimated cost function is nondecreasing and globally convex in output quantities, and nonincreasing and globally concave in quasi-fixed factor quantities. Parameters associated with dummy variables are generally not significantly different from zero at the $5 \%$ significance level. But the null hypothesis that all parameters of regional dummy variables (simple and cross terms) equal zero is not accepted at the $5 \%$ significance level. Furthermore, the null hypothesis that only parameters associated with interaction terms "regional dummy - milk output" equal zero is also not accepted at the $5 \%$ significance level, when tested against the full specification. For any farmer $n$, the marginal cost of milk is an increasing function of milk quantity and a decreasing function of other products, quasi-fixed factor levels and farmer age (for more details, see Delache et al., 1994).

\section{ii) the no-siphon quota market}

The estimated coefficients of the restricted cost function are used to analyse the consequences of implementing a (leasing) no-siphon milk quota market. Differentiating the cost function with respect to milk output, we obtain the marginal cost function of milk production. Equation (3) is then solved for $y_{1}^{n}$ to determine the optimal level of milk production $y_{1}^{t, n}$ for any farmer $n$ and the rental price of milk quota $r^{*}$ is obtained by equating the sum of optimal levels of milk production with the sum of initial quotas. 
At this stage, three practical remarks are in order. First, since our sample shows important cross-sectional variations in milk output prices, we do not assume that all farmers face the same milk price. Consequently, milk prices differ among producers and the common milk price $p$ in equations (3) or (4) is replaced by individual prices $p^{n}$. Second, we allow capacity productions (buildings, machinery and cattle) to adjust in response to milk quantity changes. The marginal cost function of milk production is then $\partial C^{n}\left(y^{n}, Z^{n}, A^{n}, D\right) / \partial y_{1}=\partial C^{n}(.) / \partial y_{1}+\partial C^{n}(.) / \partial Z_{1} \partial Z_{1}^{n} / \partial y_{1}$, where the second right-hand term of this equality represents the change in cost due to the adjustment of capital. This term may be written in terms of the sole parameters of the estimated cost function (for more details, see Delache et al.). Third, the problem of producers who lease out all of their initial endowment is solved by an iteration process : i) we define a first equilibrium using the whole sample, ii) we exclude farmers who would have a negative level of milk production at this point, iii) we define a second equilibrium on the sub-sample of producers with a positive level of milk, and iv) we iterate over steps ii) and iii) until we obtain an equilibrium where all remaining farmers produce a positive level of milk.

The no-siphon quota market is characterised by an equilibrium rental price of 117,70 francs per hectolitre ( $59 \%$ of average milk price ${ }^{3}$ ), an exchanged quantity of 724 hectolitres per farm ( $40 \%$ of initial endowment) and a producer surplus increase of 12690 francs $(6.4 \%$ of initial producer welfare) per farm.

\section{iii) the supply and demand functions of quota}

In order to analyse the consequences of the three options for the siphon defined in Section 2 , we need first an estimation of quota supply and demand functions. These functions are obtained by generating, for a given quota price ranking from 80 French francs per hectolitre to 130 French francs per hectolitre, potential quota supplies and demands. We regress then these quantities on corresponding quota prices in order to obtain an estimate of supply and demand functions of quota at the industry level. Results presented below correspond to a log-log specification which is not rejected at the $5 \%$ level of significance when tested against the more general Box-Cox specification.

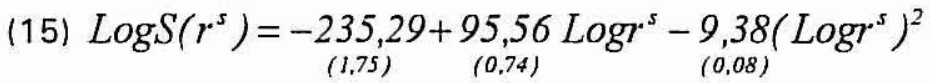

$$
\begin{aligned}
& \bar{R}^{2}=0,999 ; \text { standard errors in parentheses }
\end{aligned}
$$

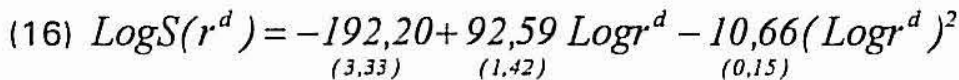

$$
\begin{aligned}
& \bar{R}^{2}=0,996 \text {; standard errors in parentheses }
\end{aligned}
$$

At the no-siphon quota market equilibrium, supply and demand quota functions are highly elastic. At this point, the elasticity of quota supply with respect to quota price is 6.10 and the elasticity of quota demand with respect to quota price is -8.99 . The price elasticity of supply decreases with quota price and is positive until a price of 162.66 French francs per hectolitre. The price elasticity of demand increases with quota price and is negative when the price is greater than 77.04 French francs 
per hectolitre. These results suggest that implementing a siphon, whatever the option chosen, would not substantially increase prices of quota demand (see equations (8), (10) and (14)). According to theoretical results presented in Section 2, the hierarchy of equilibrium demand prices would be $r_{3}^{* d}>r_{2}^{* d}>r_{1}^{* d}>r^{*}$. Since demand for quota is elastic, the third option would lead to a decrease in the equilibrium supply price of quota $\left(r_{3}^{* s}<r^{*}\right)$ and thus to a decrease in sellers' welfare. The hierarchy of equilibrium supply prices would be $r_{1}^{*_{s}}>r_{2}^{* s}=r^{*}>r_{3}^{* s}$. Finally, these figures suggest that the cost of the siphon which should be funded from outside under options one and two would be large, and that the self-financing scheme would lead to a drastic reduction in traded quantity.

\section{iv) the three options for a siphon on marketed quota}

Table 1 summarises information on the siphon quota market for the three options described in Section 2. We assume that the rate of siphon is $10 \%$.

\section{(insert Table 1)}

We start from an equilibrium corresponding to a price of 117.70 French francs per hectolitre and to an exchanged quantity of 1.115 million hectolitres, i.e., 724 hectolitres per farm. The first scheme leads to an equilibrium price of 118.52 French francs per hectolitre $(0.70 \%$ higher than the no-siphon price). The supply of quota increases from 1.114 to 1.162 million hectolitres $(+4.3 \%)$, but the quantity available for purchase decreases from 1.114 to 1.046 million hectolitres $(-6.1 \%)$. The siphoned quantity is 116258 hectolitres for a cost of 13.78 million French francs which must be funded from outside the market. In the case of scheme two, buyer price would be $1.16 \%$ higher than seller price (119.06 and 117.70 French francs per hectolitre, respectively). Of 119.06 French francs, 1.36 franc per hectolitre would be retained to help fund the siphon. The siphoned quantity is slightly lower than with the first scheme (111489 hectolitres instead of 116258 hectolitres). The total cost of the siphon is 13.12 million French francs of which 12.97 (98.9\%) must be funded from outside the market. The third scheme is self-funding. It leads to the highest demand price (123.67 French francs) and to the lowest supply price (111.31 French francs). The supply of quota is now 0.771 million hectolitres (- $30.8 \%$ with respect to the quantity supplied in the no-siphon market) and the quantity available for purchase is 0.694 million hectolitres. The siphoned quantity is then equal to 77147 hectolitres for a cost of 8.59 million francs which is totally borne by quota purchasers and sellers.

Producers' income increases by 12690 francs in average in the case of the no-siphon quota market: suppliers' income gain is, in average, slightly larger than purchaser's income increase (12963 francs and 12268 francs, respectively). Under option one for the siphon, suppliers' income gain is larger (13933 francs) but purchaser's income gain is lower (10868 francs). Under option two, suppliers' income gain is unchanged at 12268 francs but quota purchasers suffer a loss: their gain is now equal to 9997 francs. Under option three, supplier's and purchaser's welfare increases are much lower: 6749 francs and 3881 francs, respectively. 


\section{Conclusion}

As noted by Burrell (p. 117), «the main argument for a market in quota is that it encourages quota transfer from less efficient to more efficient producers». It is generally acknowledged that a quota market, in which quotas are freely transferable, either by lease or sale, separately from other assets, is cost-efficiency and welfare improving. But it is also clear that supply management policies, even if quota rights are fully transferable between producers, rise barriers to new entrants. A siphon on quota transfers can lower these barriers.

This note provides an analytical framework for modelling such a siphon on quota transfers for general supply and demand functions for quota rights. We analyse the three options for the siphon defined by Burrell and characterise the comparative statics of equilibrium prices and quantities on the quota market. A siphon mechanism will always increase demand price for quota and hence, decrease purchaser's income gain. The effects on suppliers depend upon the implemented scheme. In the first option where the cost of the siphon is funded from outside the market, purchasers' income gain increases. In the case of a self-funding scheme, purchaser's welfare gain increases (respectively decreases) if the demand function for quota rights is inelastic (respectively elastic). This theoretical framework is applied on a sample of milk producers in France for the year 1991. Supply and demand functions for quota rights are found to be very elastic which means that a self-funding scheme would lead to a drastic reduction in traded quantity and producer's income gains and that a scheme which would be funded from outside the market would be very costly.

The aim of this note was simply to propose a framework for analysing a siphon on quota transfers and to show how this framework could be empirically implemented. But our analysis should not leave the impression that supply control policies are first-best methods to reduce price distortions generated by farm policies. 
Table 1. Three option for a siphon on quota transfers : main effects

\begin{tabular}{|l|c|c|c|c|}
\hline & \multirow{2}{*}{$\begin{array}{c}\text { No-siphon quota } \\
\text { market }\end{array}$} & \multicolumn{3}{|c|}{ Siphon quota market } \\
\cline { 3 - 5 } & & Option 1 & Option 2 & Option 3 \\
\hline $\begin{array}{l}\text { Supply price of quota (French francs } \\
\text { per hectolitre) }\end{array}$ & 117.7 & $118.5(+0.7 \%)$ & 117.7 & $111.3(-5.4 \%)$ \\
\hline $\begin{array}{l}\text { Demand price of quota (French } \\
\text { francs per hectolitre) }\end{array}$ & 117.7 & $118.5(+0.7 \%)$ & $119.1(+1.2 \%)$ & $123.7(+5.1 \%)$ \\
\hline $\begin{array}{c}\text { Producer welfare gain (French francs) } \\
\text { buyers } \\
\text { purchasers }\end{array}$ & 12963 & $13933(+7.5 \%)$ & 12963 & $6749(-48.0 \%)$ \\
\hline $\begin{array}{l}\text { Supply of quota (million hectolitres) } \\
\text { nef }\end{array}$ & 12268 & $10868(-11.4 \%)$ & $9997(-18.5 \%)$ & $3881(-68.4 \%)$ \\
\hline Demand of quota (million hectolitres) & 1.115 & $1.162(+4.2 \%)$ & 1.115 & $0.771(-30.8 \%)$ \\
\hline
\end{tabular}

Note : Option 1 corresponds to the case where the cost of the siphon is borne by taxpayers; option 2 corresponds to the case where the cost of the siphon is supported by taxpayers and quota purchasers; and option 3 corresponds to the case where the cost of the siphon is funded by quota purchasers and buyers (self-funding siphon). In parentheses, changes with respect to the no-siphon quota market. 


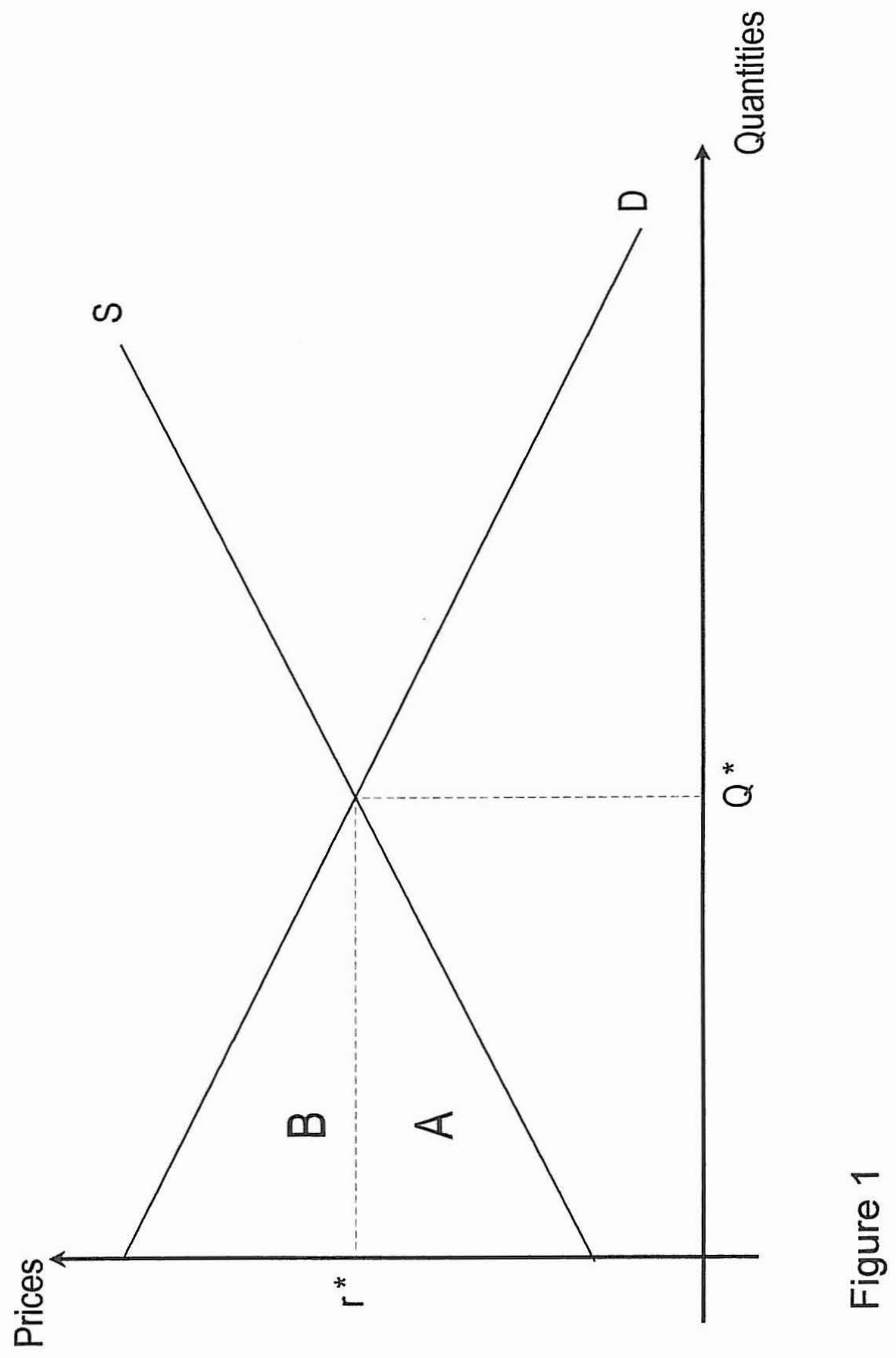




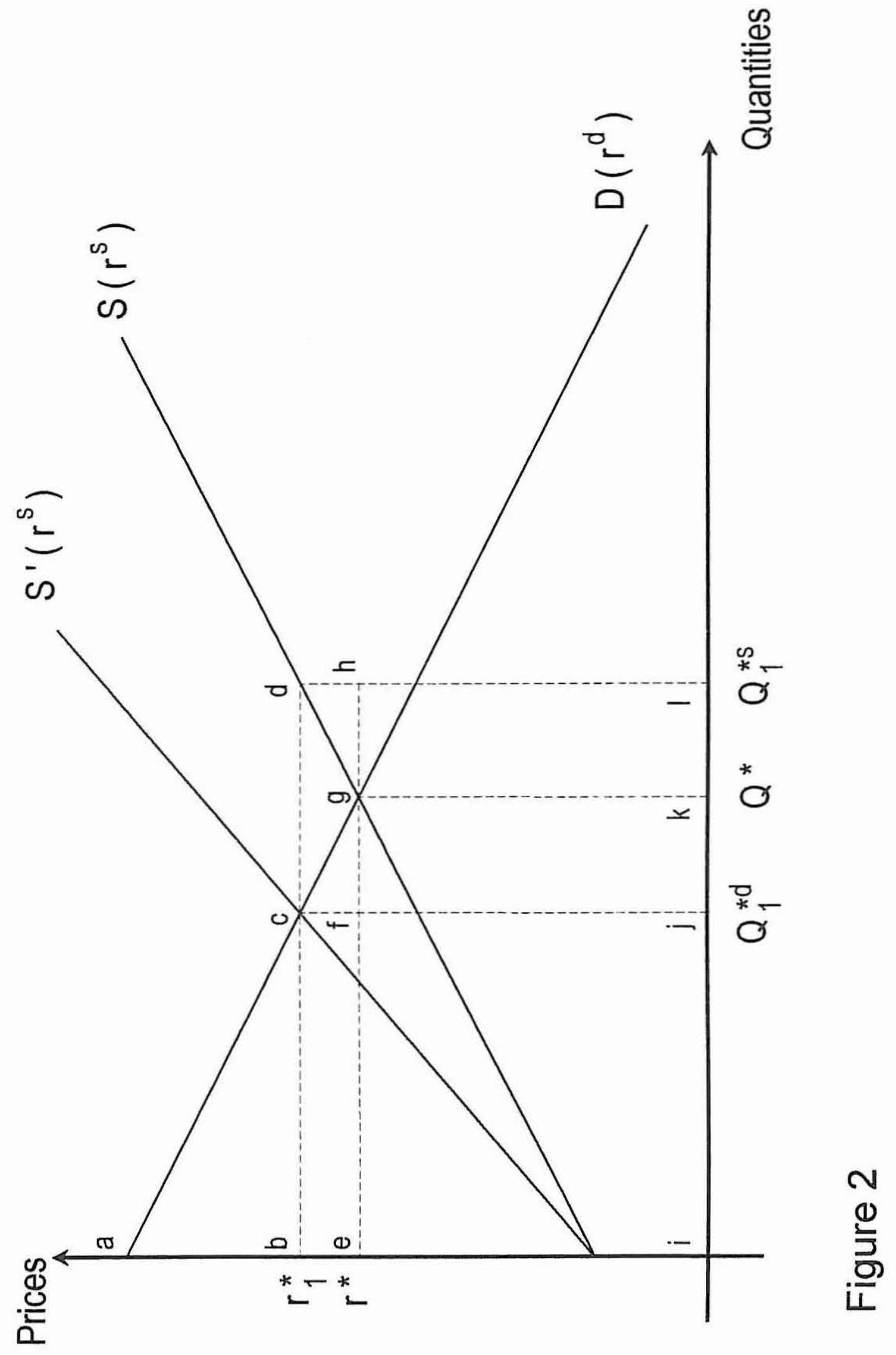




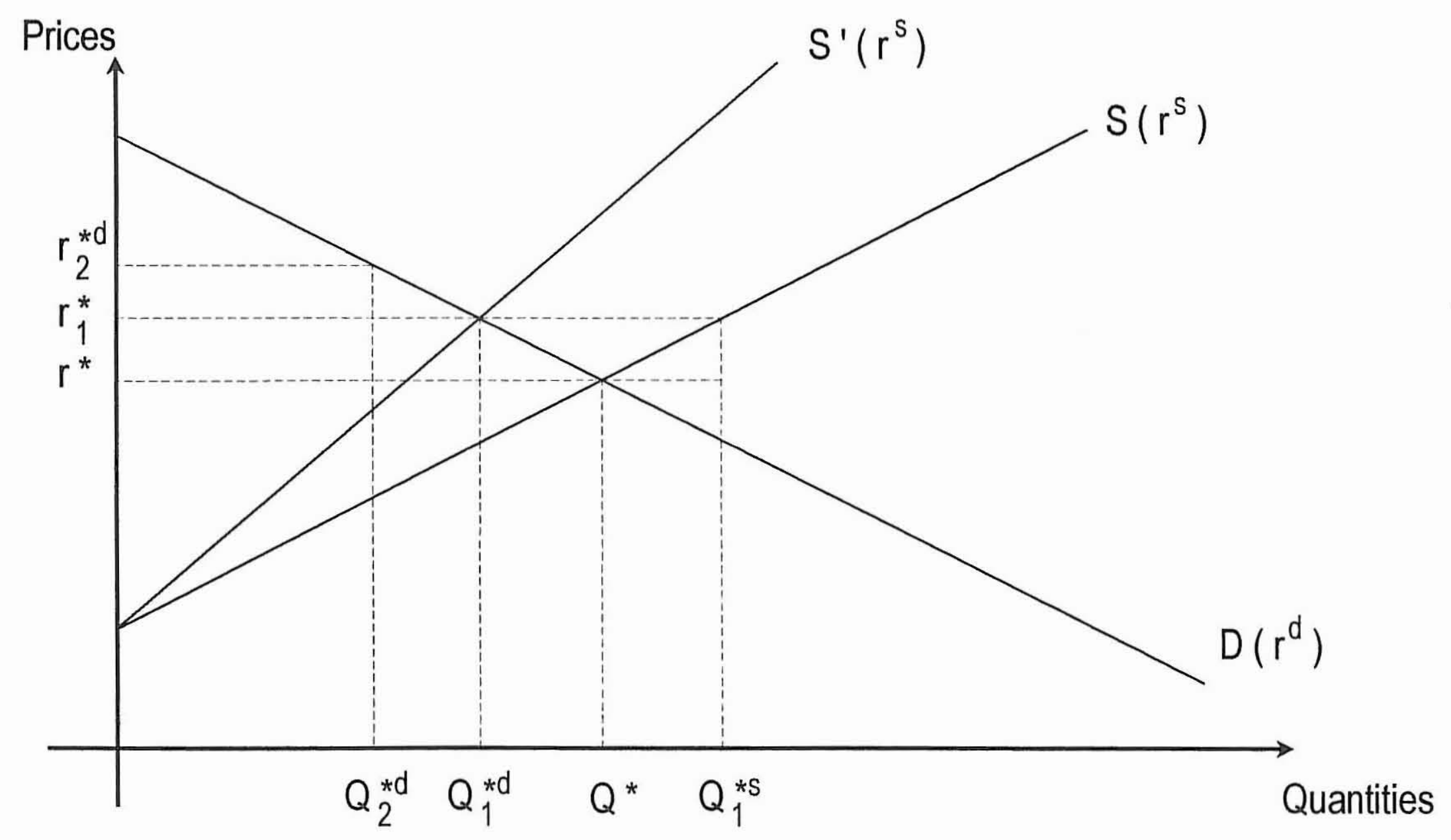

Figure 3 


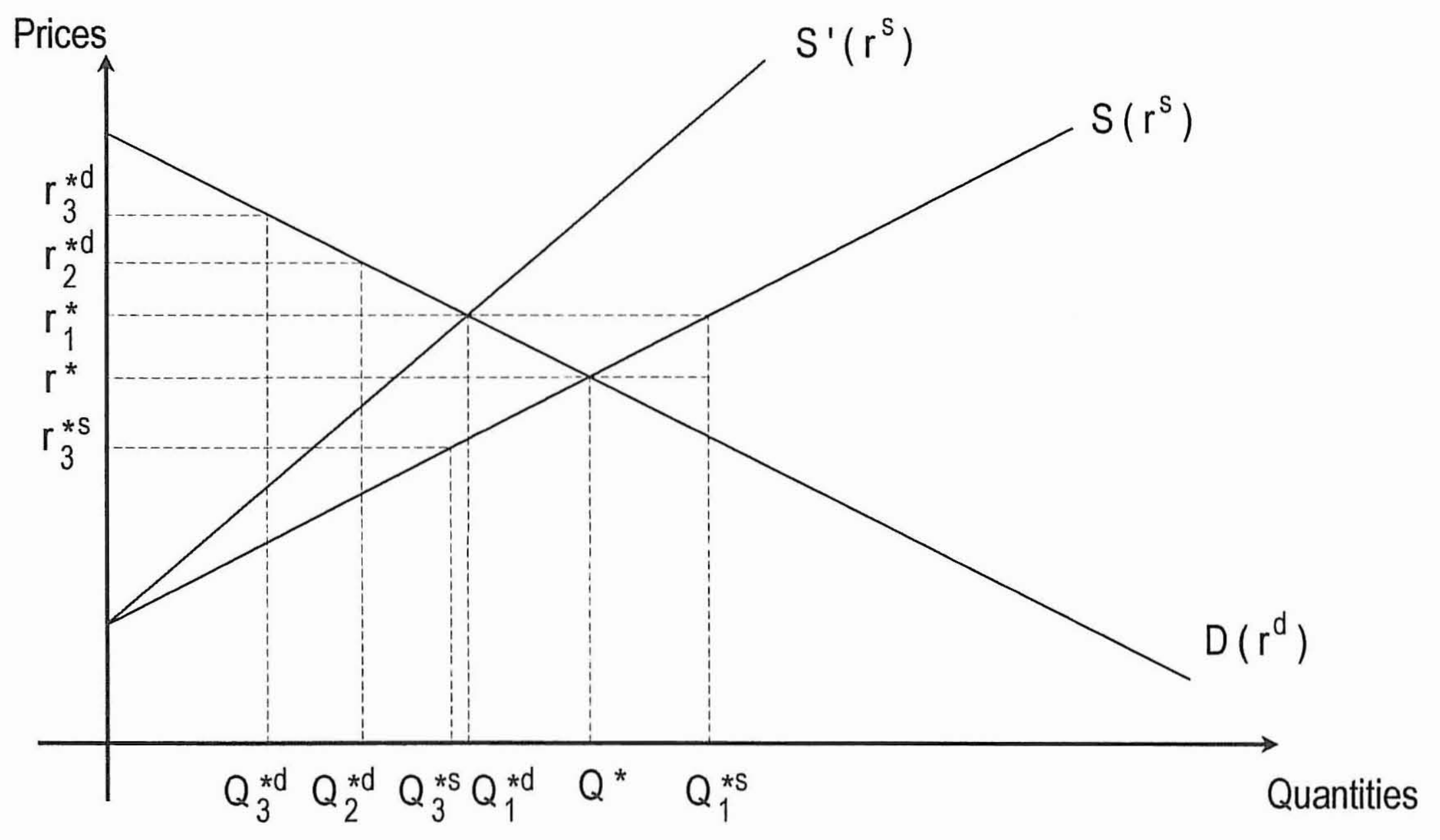

Figure 4 


\section{References}

Alston, J. M. (1981) A Note on the Effects of Non-Transferable Quotas on Supply Functions, Review of Marketing and Agricultural Economics, 49, pp.186-196.

Alston, J. M. (1992) Economics of Commodity Supply Controls, In: T. Becker, R. Gray and A. Schmitz (Eds) Improving Agricultural Trade Performance under the GATT (Wissenschaftsverlag Vauk Kiel KG).

Babcock, B. A. and Foster W. E. (1992) Economic Rents under Supply Controls with Marketable Quota, American Journal of Agricultural Economics, 74, pp. 630-637.

Burrell, A. (1989) The Microeconomics of Quota Transfer, In: A. Burrell (Ed) Milk Quotas in the European Community (CAB International, Wallingford, Oxon).

Burton, M. P. (1989) Changes in Regional Distribution of Milk Production, In: A. Burrell (Ed) Milk Quotas in the European Community (CAB International, Wallingford, Oxon).

Butcher, W. R. and Heady, E. O. (1963) Negotiable Feed Grain Output Quotas: An Estimate of Marginal Value and Exchange, Journal of Farm Economics, 45, pp. 780-88.

Cox, P. G. (1987) The Case for Tradeable Milk Production Quotas: A Note, Irish Journal of Agricultural Economics and Rural Sociology, 12, pp. 95-102.

Dawson, P. J. (1991) The simple Analytics of Agricultural Production Quotas, Oxford Agrarian Studies, 19 , pp. $127-141$.

Delache, X., Guyomard, H., Irz, X. and Mahé, L.-P. (1994) A Micro-Econometric Analysis of Milk Quota Transfer: Application to France, Working Paper 94-05, INRA-ESR, Rennes.

Guyomard, H. and Mahé, L.-P. (1993) Producer Behaviour Under Rationing with Tradable Rights, Working Paper 93-07, INRA-ESR, Rennes.

Harvey, D. (1984) Saleable Quotas, Compensation Policy and Reform of the CAP, in K. J. Thomson and R. W. Warren (Eds) Price and Market Policies in European Agriculture (Proceedings of the Sixth Symposium of the EAAE, Newcastle upon Tyne).

Hollander, A. (1993) Restricting Intra-Industry Quota Transfers in Agriculture: Who Gains, Who Loses? Canadian Journal of Economics, 26, pp. 969-975.

Hubbard, L. J. (1992) The Price of Milk Quota in England and Wales, Oxford Agrarian Studies, 20, pp. 117-128.

Moschini, G. (1984) Quota Values Under Price Uncertainty, Canadian Journal of Agricultural Economics, 32, pp: 223-235.

Rothbarth, E. (1941) The Measurement of Change in Real Income under Conditions of Rationing, Review of Economics Studies, 8, pp. 100-107.

Swinbank, A. and Peters, G. H. (1990) Who Pays a Tax in Kind ? Oxford Agrarian Studies, 18, pp.123132.

\footnotetext{
${ }^{1}$ In order to simplify the presentation of the theoretical model, we assume that, i) all producers face the same milk price and ii) all producers continue to produce a positive level of output in the regime of tradable quota rights. We will relax these assumptions in the empirical application.

2 The comparative statics of output supply, at both the firm and industry level, and of traded quantity can also be derived (Guyomard and Mahé, 1993). The most interesting result is that these quantities are invariant with respect to changes in output price. This can easily be verified by noting that output supply is a function of the difference $p-r^{*}$ and that $\partial r^{*} / \partial p=1$.

${ }^{3}$ An equilibrium milk quota price of 117,7 French francs per hectolitre may appear too high when compared to 1991 milk prices, 199.0 French francs per hectolitre in average. But it is worth noting that the use of different functional forms for the restricted cost function (i.e., the translog and the generalised Leontieff) lead to similar leasing quota prices.
} 
90-01 L'IMPACT DE LA PROPOSITION AMERICAINE AU GATT SUR LES AGRICULTURES DE LA CEE ET DES USA. Hervé GUYOMARD, Louis-P. MAHE, Christophe TAVERA (1990).

90-02 AGRICULTURE IN THE GATT : A QUANTITATIVE ASSESSMENT OF THE US 1989 PROPOSAL. Hervé GUYOMARD, Louis-P. MAHE, Christophe TAVERA (1990).

90-03 EC-US AGRICULTURAL TRADE RELATIONS : DO POLITICAL COMPROMISES EXIST ? Louis-P. MAHE, Terry L. ROE (1990).

90-04 ANALYSE MICRO-ECONOMIQUE DE L'EXPLOITATION AGRICOLE. Catherine BENJAMIN (1990).

90-05 PSE, AMS AND THE CREDIT FOR SUPPLY MANAGEMENT POLICIES IN THE GATT NEGOTIATIONS (application to the EC case). Hervé GUYOMARD, Louis-P. MAHE (1990).

90-06 COMPLETING THE EUROPEAN INTERNAL MARKET AND INDIRECT TAX HARMONIZATION IN THE AGRICULTURAL SECTOR. HEIVÉ GUYOMARD, LOUIS-P. MAHE (1990).

90-07 ALIMENTATION ANIMALE ET DYNAMIQUE DES PRIX DES MATIERES PREMIERES SUR LE MARCHE FRANCAIS. Yves DRONNE, Christophe TAVERA (1990).

91-01 ECONOMIC BEHAVIOUR OF AGRICULTURAL HOUSEHOLDS: IMPLICATIONS OF ASSUMING PERFECT SUBSTITUTABILITY BETWEEN LABOURS. Catherine BENJAMIN, Hervé GUYOMARD (1991).

91-02 LIMITATION DES IMPORTATIONS EUROPEENNES DE SUBSTITUTS DES CEREALES : IMPACT BUDGETAIRE ET DE BIEN-ETRE ECONOMIQUE. Chantal LE MOUEL (1991).

91-03 L'EVOLUTION DE LA POLITIQUE AGRICOLE COMMUNE ET SON IMPACT SUR LES PRODUCTIONS ET REGIONS AGRICOLES FRANCAISES. Hervé GUYOMARD, Yves LEON (1991).

91-04 PUBLIC INPUTS, ALLOCATABLE FIXED FACTORS AND THE THEORY OF THE MULTIPRODUCT FIRM : A CLARIFICATION. Hervé GUYOMARD (1991).

91-05 LA REFORME DE LA PAC : Une révolution ou un grand pas dans la bonne direction? Hervé GUYOMARD, Louis-P. MAHE (1991).

92-01 LA POLITIQUE AGRICOLE COMMUNE DANS L'ETAU DE L'URUGUAY ROUND. Hervé GUYOMARD, Louis-P. MAHE (1991).

92-02 TRADE COMPROMISES BETWEEN THE EC AND THE US : An Interest Group - Game Theory Approach. Martin JOHNSON, Louis-P. MAHE, Terry L. ROE (1992).

92-03 LE PROJET Mac SHARRY : facteurs de sensibilité du débouché céréalier communautaire. Hervé GUYOMARD, Louis-P. MAHE (1992).

92-04 JOINT DECISION IN LABOUR SUPPLY AND DEMAND BEHAVIOUR : AN ANALYSIS OF FRENCH AGRICULTURAL HOUSEHOLDS. Catherine BENJAMIN, Hervé GUYOMARD (1992).

92-05 MODELE DE TRANSMISSION DES PRIX GARANTIS DE CEREALES DANS LA COMMUNAUTE ECONOMIQUE EUROPENNE: DEVELOPPEMENTS THEORIQUES ET APPLICATION A LA FRANCE. Yves SURRY (1992). 
92-06 IMPORT TARIFFS, DOMESTIC DISTORTIONS AND "MARKET LINKAGES". Chantal LE MOUEL (1992).

93-01 CONSEQUENCES DE LA REFORME DE LA PAC SUR L'AGRICULTURE BRETONNE. Anne-Marie PELHERBE (1992).

93-02 LA REFORME DE LA PAC ET LES NEGOCIATIONS DU GATT - QUELLE COMPATIBILITE ? Hervé GUYOMARD, Louis-P. MAHE (juin 1992).

93-03 THE EC AND US AGRICULTURAL TRADE CONFLICT AND THE GATT ROUND : PETTY MULTILATERALISM ? Hervé GUYOMARD, Louis-P. MAHE, Terry L. ROE (1993).

93-04 DECISIONS DE TRAVAIL DES MENAGES AGRICOLES FRANCAIS. Catherine BENJAMIN, Alessandro CORSI, Hervé GUYOMARD (1993).

93-05 PSE AND DISTORTING AGGREGATE MEASURE OF SUPPORT IN THE CONTEXT OF PRODUCTION QUOTAS. Hervé GUYOMARD, Louis-P. MAHE (1993).

93-06 IS A PRODUCTION QUOTA PARETO SUPERIOR TO PRICE SUPPORT ONLY? HeIVÉ GUYOMARD, Louis-P. MAHE (1993).

93-07 PRODUCER BEHAVIOUR UNDER RATIONING WITH TRADABLE RIGHTS. Hervé GUYOMARD, Louis-P. MAHE (1993).

93-08 CALCUL DES ELASTICITES PRIX ET REVENU SOUS HYPOTHESE DE BUDGETISATION PAR ETAPES : une méthode approchée. Alain CARPENTIER, Hervé GUYOMARD (1993).

94-01 LA REFORME DE LA PAC ET LES NEGOCIATIONS DU GATT. Perspectives pour l'agriculture française et communautaire. Hervé GUYOMARD, Louis-P. MAHE (1993).

94-02 L'OFFRE DE TRAVAIL DES FEMMES. Application à l'agriculture française. Catherine BENJAMIN, Hervé GUYOMARD et Michel SOLLOGOUB (1994).

94-03 LA NOUVELLE INSTRUMENTATION DE LA POLITIQUE AGRICOLE COMMUNE. Hervè GUYOMARD et Louis-P. MAHE (1994).

94-04 A NOTE ON THE ESTIMATION OF PRICE FUNCTIONS. Ludo PEETERS et Yves SURRY (1994).

94-05 A MICRO-ECONOMETRIC ANALYSIS OF MILK QUOTA TRANSFER: APPLICATION TO FRANCE. Xavier DELACHE, Hervé GUYOMARD, Louis-P. MAHE, Xavier IRZ (1994).

94-06 ANALYSE MICRO-ECONOMIQUE D'UN MARCHE DES DROITS A PRODUIRE: APPLICATION AUX QUOTAS LAITIERS EN FRANCE. Xavier DELACHE, Catherine GOUDOUNECHE, Hervé GUYOMARD, Louis-P. MAHE, Xavier IRZ. (1994).

94-07 TENDERS FOR EUROPEAN CEREAL EXPORT REFUNDS: A STRUCTURAL APPROACH, Jean-Marc BOURGEON, Yves LE ROUX (1994).

94-08 MODELLING A SIPHON ON QUOTA TRANSFERS : APPLICATION TO MILK IN FRANCE, Hervé GUYOMARD, Louis-P. MAHE (1994). 